\title{
Should we redefine the concept of endophenotype in schizophrenia?
}

\section{Devemos redefinir o conceito de endofenótipo na esquizofrenia?}

In the last 30 years, research has focused upon the discovery of potential neurobiological correlates of schizophrenia to improve the understanding of the pathophysiological processes involved. Although aberrant processes have been identified, it still remains unclear as to what extent these abnormalities are enduring traits that are linked to the genetics and present early in the course of the disorder (i.e. endophenotypes), or state indices of non-genetic origin ("biomarkers). ${ }^{1}$

Studies involving chronically ill patients have proposed that neurobiological abnormalities (including neuropsychological, structural, and functional neuroimaging features) in schizophrenia have their bases in the early brain development ${ }^{2}$ and may be best characterized as endophenotypes. In contrast, recent studies examining pre-psychosis onset indicate that these abnormalities are initially absent or mild and do not appear clearly until the onset and/or the first few years of illness. ${ }^{3}$ In an attempt to clarify whether neurobiological findings in schizophrenia can qualify as endophenotypes according to current conceptualizations, our research group has conducted a number of longitudinal studies investigating the structural MRI and neurocognitive profiles of individuals at ultra-high risk (UHR) for developing psychosis.

In a voxel-based morphometry study, Pantelis et al. found that, when compared to a clinical high-risk group that did not develop psychosis, individuals at high-risk who converted to psychosis showed grey matter loss in left inferior frontal, medial temporal, and inferior temporal regions, as well as in the mid-cingulate bilaterally. ${ }^{4}$ Similarly, Fornito et al. assessed cortical thickness in the anterior cingulate in clinical high-risk subjects and found that, among those that developed psychosis, there was a specific thinning in the rostral paralimbic region bilaterally that predicted transition. ${ }^{5}$ More recently, Sun et al. identified changes in prefrontal cortical regions consistent with an accelerated rate of grey matter retraction at the earliest stages of psychosis (including pre-psychotic UHR individuals during the transition to psychosis). ${ }^{6}$ Takahashi et al. identified similar changes in the superior temporal gyrus and insula in these same cohorts. ${ }^{7,8}$ Importantly, while there were consistent findings related to progressive grey matter changes in these regions over the transition to illness in the UHR samples, changes prior to the onset of psychosis were inconsistent to identify those individuals that made the transition to illness. ${ }^{?}$
In an examination of neurocognitive processes, Wood et al. assessed the neuropsychological functioning of 16 UHR patients (7 of whom developed psychosis) at baseline and after transition to psychosis (or after 12 months). ${ }^{10}$ While the performance in most tests remained stable or improved, visuospatial memory, verbal fluency, and attentional switching showed significant decline over the transition to psychosis. These progressive impairments were not seen in the non-psychotic UHR group. Given that visuospatial memory at baseline, in particular, was also predictive of transition, these data suggest that the widely advertised cognitive trait-markers of the illness may not be stable over the transition to psychosis.

The above-mentioned imaging and cognitive findings suggest that the course of change at the early stages of the illness may be more revealing than that observed later on in chronic patients. Indeed, we suggest that the analysis of trajectories may be more informative in dissociating different populations of individuals at high risk for psychosis or other mental disorders. It would help, for example, to differentiate between normal development, neurodevelopmental delay, neurodevelopmental arrest, and neurodegenerative illnesses.

According to the classical definition, an endophenotype is a neurobiological marker that 1) differentiates people with and without psychosis; 2) is seen at all stages of the disorder (i.e., independent of clinical state), including premorbidly; and 3) is heritable and therefore present in first-degree relatives at higher rates than in the general population. ${ }^{1}$ Given the results described above and several other findings from different research groups, we believe that the classic concept of endophenotype cannot be applied to the study of schizophrenia and other disorders developing during an active stage of brain maturation in adolescence and early adulthood. We argue for a re-conceptualization of what is currently known as endophenotype in order to include the dynamic changes seen in the early stages of the disorder.

It is necessary to acknowledge the possibility that potential endophenotypes represent abnormalities in the normal maturational process. In fact, some genes related to the development of the illness might only be expressed after maturational brain processes in adolescence are complete. Accordingly, we propose that the concept of endophenotype in schizophrenia needs to be redefined in the context of 'early' versus 
'late' brain maturational processes. We recognize, though, that studies examining the heritability of dynamic brain changes in normal individuals and non-affected relatives are necessary to clarify whether the dynamic findings described above are real endophenotypes.

While the research on high-risk for psychosis is still a burgeoning field, and further research using larger cohorts is required, the available neuropsychological and neuroimaging evidence points to a number of dynamic changes occurring before, during and after the transition to frank illness, which raise concerns about the validity of current approaches to identify potential biomarkers and endophenotypes. We contend that the enhanced longitudinal characterization of these changes will provide a fruitful ground for the discovery of developmental processes that may be used as markers of impending illness onset, paving the way for targeted early intervention strategies.

Christos Pantelis, Stephen J. Wood, Dennis Velakoulis Melbourne Neuropsychiatry Centre, Department of Psychiatry, The University of Melbourne and Melbourne Health, Melbourne, Australia
Renee Testa

Melbourne Neuropsychiatry Centre, Department of Psychiatry, The University of Melbourne and Melbourne Health, Melbourne, Australia Department of Psychology and Psychiatry, Monash University, Melbourne, Australia

Leonardo F. Fontenelle

Melbourne Neuropsychiatry Centre, Department of Psychiatry, The University of Melbourne and Melbourne Health, Melbourne, Australia Anxiety and Depression Research

Program, Institute of Psychiatry, Universidade Federal do

Rio de Janeiro (UFRJ),

Rio de Janeiro, RJ, Brazil

Murat Yücel

Melbourne Neuropsychiatry Centre, Department of Psychiatry, The University of Melbourne and Melbourne Health, Melbourne, Australia Orygen Youth Health Research Centre, The University of Melbourne, Melbourne, Australia 


\section{Disclosures}

\begin{tabular}{|c|c|c|c|c|c|c|c|}
\hline $\begin{array}{c}\text { Writing group } \\
\text { member }\end{array}$ & Employment & Research grant $^{1}$ & $\begin{array}{c}\text { Other research grant } \\
\text { or medical continuous } \\
\text { education }\end{array}$ & $\begin{array}{l}\text { Speaker's } \\
\text { honoraria }\end{array}$ & $\begin{array}{c}\text { Ownership } \\
\text { interest }\end{array}$ & $\begin{array}{c}\text { Consultant/ } \\
\text { Advisory } \\
\text { board }\end{array}$ & Other $^{3}$ \\
\hline $\begin{array}{l}\text { Christos } \\
\text { Pantelis }\end{array}$ & $\begin{array}{l}\text { University of } \\
\text { Melbourne }\end{array}$ & $\begin{array}{c}\text { National Health and } \\
\text { Medical Research } \\
\text { Council } \\
\text { Australian Research } \\
\text { Council } \\
\text { AE Rowden White } \\
\text { Foundation } \\
\text { Ramaciotti } \\
\text { Foundation Pratt } \\
\text { Foundation Victorian } \\
\text { Neurotrauma Initiative } \\
\text { Australian Nuclear } \\
\text { Science \& } \\
\text { Technology } \\
\text { Organization } \\
\text { Melbourne Health } \\
\text { The University of } \\
\text { Melbourne }\end{array}$ & $\begin{array}{c}\text { Janssen-Cilag } \\
\text { Eli-Lilly } \\
\text { Hospira (Mayne) } \\
\text { AstraZeneca }\end{array}$ & - & - & $\begin{array}{l}\text { Janssen-Cilag } \\
\text { Eli-Lilly } \\
\text { Hospira } \\
\text { (Mayne) } \\
\text { AstraZeneca } \\
\text { Pfizer } \\
\text { Schering } \\
\text { Plough }\end{array}$ & - \\
\hline $\begin{array}{l}\text { Stephen J. } \\
\text { Wood }\end{array}$ & $\begin{array}{l}\text { University of } \\
\text { Melbourne }\end{array}$ & $\begin{array}{c}\text { National Health \& } \\
\text { Medical Research } \\
\text { Council }\end{array}$ & $\begin{array}{l}\text { NARSAD Young } \\
\text { Investigator Award }\end{array}$ & - & - & - & - \\
\hline $\begin{array}{l}\text { Dennis } \\
\text { Velakoulis }\end{array}$ & $\begin{array}{l}\text { University of } \\
\text { Melbourne }\end{array}$ & - & - & - & - & - & - \\
\hline $\begin{array}{l}\text { Renee } \\
\text { Testa }\end{array}$ & $\begin{array}{l}\text { University of } \\
\text { Melbourne } \\
\text { Monash } \\
\text { University }\end{array}$ & - & - & - & - & - & - \\
\hline $\begin{array}{l}\text { Leonardo F. } \\
\text { Fontenelle }\end{array}$ & $\begin{array}{l}\text { UFRJ } \\
\text { UFF }\end{array}$ & $\begin{array}{l}\text { CNPq } \\
\text { FAPERJ }\end{array}$ & $\begin{array}{c}\text { Bolsa Produtividade } \\
\text { CNPq } \\
\text { Endeavour Post- } \\
\text { doctoral Research } \\
\text { Fellowship, Australian } \\
\text { Government } \\
\end{array}$ & Eli-Lilly & - & - & $\begin{array}{c}\text { Solvay } \\
\text { Lundbeck } \\
\text { Servier }\end{array}$ \\
\hline $\begin{array}{l}\text { Murat } \\
\text { Yücel }\end{array}$ & $\begin{array}{l}\text { University of } \\
\text { Melbourne }\end{array}$ & $\begin{array}{l}\text { National Health \& } \\
\text { Medical Research } \\
\text { Council }\end{array}$ & - & - & - & - & - \\
\hline \multicolumn{8}{|c|}{$\begin{array}{l}\text { *Modest } \\
\text { ** Significant } \\
\text { *** Significant: Amounts given to the author's institution or to a colleague for research in which the author has participation, not directly to the } \\
\text { author. } \\
\text { Note: UFRJ = Universidade Federal do Rio de Janeiro; UFF = Universidade Federal Fluminense; CNPq = Conselho Nacional de Ciência e } \\
\text { Desenvolvimento Tecnológico; FAPERJ = Fundação de Amparo à Pesquisa do Estado do Rio de Janeiro; NARSAD = National Alliance for } \\
\text { Research on Schizophrenia and Depression. } \\
\text { For more information, see Instructions for authors. }\end{array}$} \\
\hline
\end{tabular}

References

1. Gottesman II, Gould TD. The endophenotype concept in psychiatry: etymology and strategic intentions. Am J Psychiatry. 2003;160(4):636-45.

2. Murray RM, Lewis SW. Is schizophrenia a neurodevelopmental disorder? $\mathrm{Br}$ Med J (Clin Res Ed). 1987;295(6600):681-2.

3. Wood SJ, Pantelis C, Velakoulis D, Yücel M, Fornito A, McGorry PD. Progressive changes in the development towards schizophrenia: studies in subjects at increased symptomatic risk. Schizophr Bull. 2008;34(2):322-9.

4. Pantelis C, Velakoulis D, McGorry PD, Wood SJ, Suckling J, Phillips LJ, Yung AR, Bullmore ET, Brewer W, Soulsby B, Desmond P, McGuire PK. Neuroanatomical abnormalities before and after onset of psychosis: a cross-sectional and longitudinal MRI comparison. Lancet. 2003;361(9354):281-8.

5. Fornito A, Yung AR, Wood SJ, Phillips LJ, Nelson B, Cotton S, Velakoulis D, McGorry PD, Pantelis C, Yücel M. Anatomic abnormalities of the anterior cingulate cortex before psychosis onset: an MRI study of ultrahigh-risk individuals. Biol Psychiatry. 2008;64(9):758-65.

6. Sun D, Phillips L, Velakoulis D, Yung A, McGorry PD, Wood SJ, van Erp TG, Thompson PM, Toga AW, Cannon TD, Pantelis C. Progressive brain structural changes mapped as psychosis develops in 'at risk' individuals. Schizophr Res. 2009;108(1-3):85-92.

7. Takahashi T, Wood SJ, Yung AR, Soulsby B, McGorry PD, Suzuki M, Kawasaki Y, Phillips LJ, Velakoulis D, Pantelis C. Progressive gray matter reduction of the superior temporal gyrus during transition to psychosis. Arch Gen Psychiatry. 2009;66(4):366-76.

8. Takahashi T, Wood SJ, Yung AR, Phillips LJ, Soulsby B, McGorry PD, Tanino R, Zhou SY, Suzuki M, Velakoulis D, Pantelis C. Insular cortex gray matter changes in individuals at ultra-high-risk of developing psychosis. Schizophr Res. 2009;111(1-3):94-102.

9. Takahashi T, Wood SJ, Yung AR, Walterfang M, Phillips LJ, Soulsby B, Kawasaki Y, McGorry PD, Suzuki M, Velakoulis D, Pantelis C. Superior temporal gyrus volume in antipsychotic-naive people at risk of psychosis. $\mathrm{Br} J$ Psychiatry. 2010;196:206-11.

10. Wood SJ, Brewer WJ, Koutsouradis P, Phillips LJ, Francey SM, Proffitt TM, Yung AR, Jackson HJ, McGorry PD, Pantelis C. Cognitive decline following psychosis onset: data from the PACE clinic. Br J Psychiatry Suppl. 2007;51:S52-7. 